\title{
Film modernism
}

Sam Rohdie 


\section{Copyright (C) Sam Rohdie 2015}

The right of Sam Rohdie to be identified as the author of this work has been asserted by him in accordance with the Copyright, Designs and Patents Act I988.

Published by Manchester University Press

Altrincham Street, Manchester Mi 7JA

www.manchesteruniversitypress.co.uk

British Library Cataloguing-in-Publication Data

A catalogue record for this book is available from the British Library

Library of Congress Cataloging-in-Publication Data applied for

ISBN 978 ० 7190 9928 I paperback

First published 2015

The publisher has no responsibility for the persistence or accuracy of URLs for any external or third-party internet websites referred to in this book, and does not guarantee that any content on such websites is, or will remain, accurate or appropriate.

\section{Typeset by}

Servis Filmsetting Ltd, Stockport Cheshire

Printed in Great Britain

by Bell \& Bain Ltd, Glasgow 